\title{
Building governance in the international financial system: Context and challenges*
}

\author{
Governabilidade no sistema financeiro \\ internacional: contexto e desafios
}

LEANDRO PIGNATARI SILVA**

\begin{abstract}
RESUMO: O sistema financeiro internacional sofreu profundas mudanças desde a década de 1970 e sua estabilidade não pode ser alcançada a despeito dos interesses do ator ou a existência de inúmeras instâncias de coordenação. Analisando a estrutura de incentivos do sistema, pode-se notar que a sua estabilidade depende do controle dos desequilíbrios, que nem sempre são prejudiciais para os Estados, criando, assim, um componente perturbador na busca pela gestão financeira internacional. Além disso, os atores não estatais têm adquirido uma participação desproporcional de poder após a globalização financeira, fugindo do controle dos Estados e da comunidade internacional.

PALAVRAS-CHAVE: globalização financeira; governabilidade; atores não estatais.
\end{abstract}

ABSTRACT: The international financial system has undergone deep changes since the 1970 s and its stability cannot be reached in spite of actor's interests or the existence of countless coordination fora. Analyzing the system's incentive structure, one can note that its stability depends on the control of imbalances, which are not always harmful for States, creating, thus, a disturbing component in the quest for international financial management. Furthermore, non-state actors have acquired a disproportional share of power following financial globalization, escaping the control of States and of the international community. KEYWORDS: financial globalization; governance; non-state actors.

JEL Classification: F59.

\section{INTRODUCTION}

Economics can be seen as one of the few fields in which international rules work considerably well, with no need for explicit calls for the ideal of public good.

\footnotetext{
* The opinions in this article are exclusively personal and do not reflect the official position of the Brazilian Government

* * Instituto Rio Branco, Brasil, diplomata. E-mail: leandro.pignatari@itamaraty.gov.br. Submetido: 19/ novembro/2012; Aprovado: 19/setembro/2014.
} 
The dissemination of liberal ideas, especially from the end of the Cold War, has majorly contributed towards the construction of a consensus regarding the benefits of free trade and free capital flows, which, in its turn, allows for the concoction of noticeably efficient regimes based on the interests of individual States. The efforts aimed at promoting trade and at stabilizing the international financial system, however, can already be found since Bretton Woods, for finance, and the GATT, for trade. From the financial perspective, focus of this paper, the first enterprises of international coordination were aimed at the creation of a new stability paradigm to replace the one lost with the end of the gold standard.

Economic, commercial or financial regimes are, differently from others, such as those pertaining to human rights or to the environment, characterized by governance without government. The element responsible for this difference is, undoubtedly, the presence of a market, which allows for the functioning of the system even without the acting presence of the State. Even if we draw from Polanyi's argument that there can be no market without the State (1944, apud Underhill), having the former actually been structured and assured by the latter, the differentiating element remains in the fact that an impersonal entity can affect State policies and individual behavior.

Besides the "classic", or "natural", role played by private structures in the financial system, during the second half of the $20^{\text {th }}$ century there has been a real change in the authority axis, from States to markets, markedly in the productive and financial spheres, as points out Strange (1996). ${ }^{1}$ The development of a power structure parallel to that of the State, therefore, in particular when discussing the governance of the financial system, makes it essential to include non-state actors in the analysis. It does not seem adequate, however, to speak of a global civil society for two reasons: firstly, the most relevant private actors in the financial field are banks and Credit Rating Agencies (CRAs), agents that have mainly economic, not political, objectives, even though sometimes they are not easily dissociated; and, secondly, these agents, though acting internationally, or at least having actions with global effects, are eminently national or multinational.

The world economic crisis of mid-2007 is emblematic regarding the featured role played by non-state actors in the contemporary international scene. From the rupture it caused, it became inconceivable a financial stabilization arrangement that do not consider the actions of big banks and CRAs. Even if in the beginning the market depended heavily on the State, and still does so in some aspects, currently, in the credit market, core of the financial system, the State has become, to a large extent, a hostage to private agents. One must notice, nevertheless, that such a situation is not unprecedented. The history of links between government and banks is actually ancient. Excellent examples are the connections verified in Italian citystates in the $14^{\text {th }}$ century, followed by those of the Dutch banks in the $16^{\text {th }}$ and $17^{\text {th }}$

\footnotetext{
${ }^{1}$ This shift away from States and towards markets is probably the biggest change in the International Political Economy to take place in the last half of the $20^{\text {th }}$ century (Strange, 1996, p. 43).
} 
centuries and, finally, the English ones from the Industrial Revolution. During this process, however, the level of connection between private agents and governments has varied, and the banks from the $20^{\text {th }}$ century eventually dissociated themselves from national political authorities.

The attempts to create a stable system based on the coordination of States, as in Bretton Woods, end, therefore, limited to only one dimension of international finance, that controlled by States through their Central Banks and Finance Ministries, ignoring the role played by the international credit market and big investors groups that move fortunes through borders. These ignored elements, nevertheless, jeopardize the viability of the desired order, since the ensuing mechanisms are not capable of dealing with unforeseen situations.

The contemporary international context is extremely rich for the discussion of a new governance of international finance, either because of the emergence of new non-state actors, or because of the relative decline of traditional state actors concomitant with the emergence of others, or even because of a change in the financial system axis, since the 1970s, from exchange rates to credit markets. Both old and new actors, thus, debate the ways for building a more stable financial system. With no intent of exhausting the theme, this paper tries to shed some light on a few of the main elements of this new debate. The next section will analyze the changes in the international scene, from the financial perspective, highlighting the issues of actors and their goals. The following section discusses how the international governance of the financial system is built, considering governance-power relations. The Conclusion will bring the main considerations of the paper and some issues that remain open for debate.

\section{THE CONTEMPORARY FINANCIAL SYSTEM}

The governance structure of the contemporary financial system was established in 1944, through the Bretton Woods agreements, which created the International Monetary Fund (IMF), for the stabilization of exchange rates, and the International Bank for Reconstruction and Development, which became the main institution of the World Bank Group. Worried about the instability of floating exchange rates, as it was considered then, after the end of the gold standard following World War II, the States gathered in New Hampshire decided to build a system based on a dollar-gold standard, which lasted, however, only until 1973.

Even during the gold standard period there was already tension, between the gold zone and the silver zone, solved in great part by the net externalities created by the big economies' options at the time. The possibility of resorting to distinct standards in different parts of the world is renewed with the end of Bretton Woods. When the gold anchoring of the dollar ended and the rigid exchange rate system was torn apart, the world embarked in a floating exchange rate experience that, 
nevertheless, is not shared by all countries, as shown by the European experience with the European Monetary System, forerunner of the Euro. ${ }^{2}$

Concomitant to the crises of the Bretton Woods system, the massive Eurodollars flows and the formation of a private capital market turned the major concern of the international financial system to capital movements and to the regulation of banks with international activities. In this context, the oldest international financial institution, the Bank for International Settlements (BIS), created in 1930, gained more relevance. Working as a cooperation forum among the Central Banks of member-states, the BIS became more responsible for regulation and supervision of national financial systems, creating the Basle "system", with the Basle Capital Agreement of 1988, Basle II Agreement and, more recently, Basle III, still in implementation, instead of just a support for the Bretton Woods system in the immediate post-war. These agreements are innovative because they recognize the systemic security aspect involved in the actions of private agents: their main purpose is to regulate the amount and the structure of the capital banks should keep in reserve in order to mitigate their risk exposure.

As Bordo and James (2000) show, the IMF has also had its operations modified, turning from its mandate accorded in 1944, that included the promotion of international monetary cooperation, trade facilitation, the promotion of exchange rate stability and the stimulus to the creation of a payments system, all functions deeply linked to exchange rates, to a new role with new functions. Given the formation of wide and integrated private capital markets, the IMF has begun to offer funds to countries, especially less developed ones, that could not get access to those markets, or, alternatively, to act as crises manager when private markets were quickly closed to countries with big current account deficits. The Fund took on functions similar to those of a CRA, giving "approval stamps" for national policies that could facilitate the access to private markets, but also coordinating the activities of credit suppliers during crises. Its role in supervising and quelling crises, therefore, has gained more importance. The cooperation between the IMF and the BIS in ensuring the integrity of the system remained: whereas the BIS is responsible for very-short term fund releases, the IMF acts as a financier for long term rescues.

The change of focus in the mid-1970s only deepened at the end of the century. Following the crises in Mexico, Southeast Asia and Russia, the conception of the role played by the IMF is definitively changed and the role played by the private sector during crises begun to become completely revealed. As they get involved in high-risk operations, commercial and investment banks start to ask governments and multilateral institutions for assurances for their investments. Given their size

\footnotetext{
${ }^{2}$ When countries abandoned their fixed exchange rates, given capital mobility, they could use their monetary policies towards other ends than pursuing external balance. This phenomenon happens because of the "impossible trinity" of international economics, made of fixed exchange rates, independent monetary policy and capital mobility. From these three objectives, States can attain only two simultaneously. During the Bretton Woods period, keeping fixed exchange rates meant the imposition of severe controls on capital movements, hindering the development of an international credit market.
} 
and systemic importance, keeping their economic viability is key for all actors. This situation generates a high moral risk that was present, once again, in the most recent economic crisis. ${ }^{3}$ Besides, successive financial innovations and the integration and growth of financial markets have led to a permanent change of political economy, particularly, and of international relations, overall (Verdun, 2000, p. 79).

From an institutional perspective, the G20 is created after the Asian crisis, in 1999. Other new fora were created, furthermore, within the IMF framework, as the Supplemental Reserve Facility and the Financial Stability Forum (FSF). The proliferation of crises in countries that seemed to practice rock solid economic policies happened, additionally, in a context of growing weakening of the State, who had pushed forward several liberalization policies during the 1990s that resulted in the diffusion of the state authority, which was then exercised by private actors. As Strange (1996) points out, from an analysis of structural power and power over results, it can be clearly verified the decline of the State capacity to control the effects of its policies, which is a result of an authority dissolution carried out by States themselves. For Strange, other actors are also influencing the results, besides the market, which, in its turn, is built based on expectations that turn out to be selffulfilling. ${ }^{4}$ In this context, the international community needs to accelerate the speed of its answers to potential conflicts (Verdun, 2000).

An aggravating element for the proper performance of the State in its management functions is presented by Underhill (2000), through the analysis of Strange's work. Besides the arguments already listed, Underhill believes that the transformation of the global credit creation and allocation system, based on the market and advanced by non-state actors, such as international banks, has introduced a series of new restrictions to national and international monetary management. It becomes unquestionable, then, that the presence of new actors in the contemporary financial system makes the process of governance building more complex. In addition to States that had substantial economic growth and acquired more voice in the international scene in the last decade, as the BRICS, non-state actors, as investment banks and CRAs, that often have more power than States, ${ }^{5}$ emerge as the great

\footnotetext{
${ }^{3}$ IMF intervention in crises, particularly from the Mexican one in 1982, has led the critics to highlight the creation of moral risk, not only for borrowers, who will always believe in a rescue, but also for governments, that could start practicing looser economic policies assured that the Fund would intervene if necessary (Bordo and James, 2000).

${ }^{4}$ Strange argues for the inclusion of other actors in the analysis based on the argument of power over results, but it is also possible to do so according to "traditional" criteria, as their resources. Even if there is no will to interfere, an important element considered by Strange in her power evaluation, the simple existence of entities such as investment banks, with trillion-dollar portfolios, seems sufficient to influence the policies adopted by States. This understanding would be roughly what the author calls structural power, attributed, in her analysis, to the US. How, though, not to attribute the due importance of, for instance, JP Morgan Chase, whose assets, in 2011, were over 2 trillion dollars?

${ }^{5}$ Acknowledging the role played by non-state actors is not the same as saying that States are only "pawns" in the international finance board. As capital became more mobile and transnational, private actors acquired more leverage over governments, that remained territorially restrained (Underhill, 2000).
} 
diversifiers of the international financial relations. Likewise, traditional international institutions get new contours, becoming part of the governance tissue as States try to compensate their power decline (Underhill, 2000).

The emergence of new States, besides granting more weight individually to those who got richer, has allowed for the strengthening of developing countries as a group. In this sense, it is noteworthy the adoption of the G20 as the main forum for discussions related to economic affairs over the G8. Even though this new forum has not yet dealt in breath with crucial issues as the accumulation of reserves, the participation of developing countries in the group allows for the first time in history for them to shape the international economic system (Dailami and Masson, 2009, apud Lins and Silva, 2011). In the state sphere, thus, it is already possible to notice an enlargement of the decision-making group, granting it more legitimacy, even though the admittance of developing countries did not significantly alter the positions of the bloc. Analyzing G20 declarations in comparison to the positions advocated by developing countries, particularly Brazil, Lins and Silva (2011) notice how there is no ultimate antagonism among the actors. The worries voiced are, basically, those shared by developed countries: the need for more regulation given more open capital markets, strengthening of the IMF and regional banks for the provision of liquidity to the system and the division of costs with private financial institutions.

On another perspective, financial liberalization and the high level of indebtedness of States allowed for the intensification of the phenomenon identified by Strange at the end of the $20^{\text {th }}$ century. The massive transfers of power to investment banks and to CRAs can be clearly observed: their role in the most recent economic crisis is noticed in its trigger, the bankruptcy of the US bank Lehman Brothers. The securitization advised, and concomitantly assessed, by CRAs created a context of conflict of interests resulting in the dissemination of high risk mortgage derivatives, which, notwithstanding, were positively assessed by the agencies, who did not have the adequate tools to measure the probabilities of default (Eichengreen, 2009a). Subsequently, serial negative assessments of debt bonds of Eurozone countries contributed to deepening the crisis, which then moved on to fiscal issues. In all this period, State regulators were not able to keep ahead of those regulated.

\section{BUILDING GOVERNANCE}

The stability of the international financial system has, undoubtedly, characteristics of a global public good. ${ }^{6}$ As Dent (2007) explains, from the perspective of

\footnotetext{
In Strange's argument, furthermore, it is important to precise that not all authority lost by States was captured by the private sector. For her, part of it was "lost", resulting in a vacuum. Underhill highlights, also in favor of the strengthening of non-state actors, that they act through the State, as well, influencing public policies.

${ }^{6} \mathrm{~A}$ public good is characterized by non-rivalry and non-exclusivity. If one is to add the global quality to this classification, the good must, also, be almost universal in terms of countries, people and
} 
economic security, systemic security is related to the common interest of actors in keeping the system's integrity, leading to cooperative actions designed to sustain multilateral governance regimes and thus with a great dimension of global public good. This quality, moreover, remains when stability is understood in minimalist terms, as the absence of crises. As the concept is expanded, though, even moderately, to include, for instance, the continuity of stability, it loses its characterization as a public good. This is due to the fact that building a permanent stability entails the elimination, or control, of imbalances that may, however, be beneficial for determined groups of countries, although bad for others. ${ }^{7}$

The rationale is not reverted, in spite of Cohen (2000) arguments about the long shade of future in finance, making egoism a not necessarily optimal answer to the fact that in finance the challenge of cooperation deals with a common aversions dilemma, demanding only agreements regarding the basic functioning rules of the system. The greatest problem in the construction of a perennial stability is not only the absence of cooperation, but also the fact that, when it is present, cooperation ends. In the Chinese-American case it is not possible to discard the existence of cooperation, even if tacit. It is not encouraging either the emphasis placed on "regime preservation" by common aversions dilemmas; the elimination or control of imbalances depends on the "policy coordination" that would be present in the case of a public good. ${ }^{8}$ In a wide conception, thus, systemic stability can be understood differently by each country, crossing another dimension of economic security, the one of credit and finance, for which there are incentives for an individual quest for stability. ${ }^{9}$ These, however are not compatible with the theory of harmony of interests, in which the quest for individual advantage promotes the collective well-being. The incompatibility is shown in the definition of credit and financial security proposed by Dent (2007), which includes the national interest in keeping its solvency and keeping the access to and/or influence over credit sources, tasks

generations. For further information and a deeper discussion on the theme $c f$. Kaul, Inge et al. (eds.) Global Public Goods: International Cooperation in the $21^{\text {st }}$ Century. Oxford, Oxford University Press, 1999.

${ }^{7} \mathrm{~A}$ recent example of this situation is the symbiotic relation between the USA and China, commonly referred to as Bretton Woods II. Whereas China has accumulated successive and expressive current account surpluses, the US has registered deficits. Beneficial for both parties between 2004 and 2006, the existence of such imbalance is absolutely beneficial for China, even in a crisis context. For the US, as well, the existence of this imbalance is beneficial, although in a different way, inasmuch as it allows for postponing internal adjustments that are challenged domestically. The elimination of imbalances, thus, does not constitute necessarily a good wished by all countries.

${ }^{8}$ Cohen argument has more validity if we consider that the causes of crises are found more on the nefarious effects of deregulation than on the existence of imbalances among States. Both possibilities are suitable and each results in different political prescriptions. As Eichengreen (2009a) explains, the options do not exclude each other.

${ }^{9}$ It is interesting to notice that, according to Strange, making flexible the concept of security leads, by itself, to a process of power-sharing by States, turning it even more difficult to build global governance in general and that of the financial system in particular. 
that are made difficult by the financial globalization and the increased role played by speculators. Even though smaller countries do appeal to cooperation, those with big reserves tend to base themselves only on these resources for their security and not on the support of other members of the international community.

It is necessary, thus, to conciliate the incentives and needs of cooperation and power involved in the construction of financial stability. The existing incentive structure in the contemporary international financial system does not collaborate for a deeper cooperation among States, even though there are plenty of institutions and negotiating fora, as highlights Eichengreen (2009a). There is a classic collective action problem that could be solved through the strengthening of the IMF, whose role has been diminished in line with the evolution of capital markets. With no power over countries that are not borrowers from the Fund, it is not possible for the IMF to impose sanctions on destabilizing practices, such as keeping expressive and continuing current account deficits and surpluses. It is illustrative of this juncture the fact that the Fund alerted, with no consequence, of the US deficits and of the Chinese surpluses (Eichengreen, 2009a). This comes from the situation in which a deficit country, having the supply of private capital markets, and the surplus country, with no need of capital, are, both, put outside the control of the IMF. For Eichengreen, a manner to bypass this limitation would be the mechanization of penalties in case of recurrent inadequate economic policies, through, for instance, the requirement of additional contributions to the Fund. Even if this imposes an additional cost to the practice of reserve accumulation of the surplus country, the incentive for such practice, though, is not completely eliminated. The situation of the deficit country, in its turn, would be even worsened.

To the Fund, therefore, remains the role of containing the crises caused by sudden interruptions of credit to countries with big deficits. Prevention, nevertheless, is a responsibility of States, even if domestic incentives do not lead, all the times, to the internalization of the side effects of economic policies (Eichengreen, 2009a). Prevention, thus, is done precariously, if done at all, being limited to the management of the periods of great economic expansion, with no implementation of truly anti-cyclical policies, especially in the fiscal area (Ocampo, 2002). Another important aspect of prevention, in addition to the fight against imbalances, is the strengthening of regulation. In this sense, Eichengreen (2009a, 2009b) lists as necessary i) the elevation of the level of capital kept by banks, accomplished through international cooperation with the Basle Agreements; ii) the creation of an intermediate policy between the rescue of banks and bankruptcy, considering that banks that operate internationally require coordinated actions that go beyond the national level; iii) the provision of more information to regulators and the creation of a macroprudential supervision, which must also be international. As for CRAs, the needs include better methodologies and the elimination of conflicts of interests. The challenges involved in this agenda, however, are not just a few: it is necessary to develop instruments that allow one to bring non-banking financial institutions into regulation, as well as applying the rules efficiently and systematically, avoiding that financial institutions escape national jurisdictions. Likewise, considering that 
problems of financial instability must be solved before they occur, a last resort lender should be created to act before the end of national reserves.

Also in this sense, Taylor (2002) argues that in a world with open financial markets, national governments cannot properly regulate the risks to which their economies are exposed, reinforcing the argument for international cooperation in regulation. According to Taylor, "any nations financial controls appear to be made for the sole purpose of being evaded" (p. 55), what is achieved mainly through offshore operations. Even if it is important that, internally, regulators are kept updated and a culture of probity is created in the local financial system, in a generalized confidence crisis, asserts Taylor, no regulation is enough, being necessary the existence of a lender of last resort. ${ }^{10}$

A true solution to the problem of instability in the financial system, therefore, calls for the engagement of several actors in the international field. For Ocampo (2002), the main element should be the construction of a network of regional institutions, headed by the IMF, but not the creation of a global organization that would centralize every operation, as suggested by Taylor. According to Ocampo, regional institutions would have more success given the engagement of membercountries that would share a deeper feeling of belonging. Furthermore, it is conceivable that regionalization would allow for the reduction, even if not the complete elimination, of some challenges present in any global order, as suggests the author: the reluctance to give up sovereignty, the accurate perception that institutional designs and procedures are not neutral and, to a lesser extent, the creation of instruments that reduce the cost of domestic protective policies. Eichengreen (2009a), however, reminds that regional initiatives have no better record of success than global ones. A factor leading to this a priori lack of success is exactly the limitation of available resources. The inability to ensure liquidity internationally in moments of great crises leads these countries to continue with policies envisaging reserve accumulation, incurring in chronic surpluses, creating and aggravating imbalances that, in their turn, lead to the crises States were trying to avoid. For Eichengreen (2009a), one must consider, as well, the indisposition of countries to criticize their neighbors' policies, even if ultimately their aspiration is to have the borrowings honored and resources not wasted, making regional mechanisms inadequate in favoring the necessary adjustments. ${ }^{11}$

\footnotetext{
${ }^{10}$ Currently, the IMF and the BIS play the role of lender of last resort. The BIS is responsible for the immediate support in cases of liquidity crisis, which is arranged among Central Banks, whereas the IMF gets involved in cases in which it is necessary to apply political changes and convince markets that a new phase will be inaugurated, restoring confidence in the aftermath of a collapse. In this sense, the Fund's answer, especially to the Mexican crisis in 1994, has created a precedent, encouraging investors to believe that an international rescue package would protect them against losses. By the end of the day, liquidity crises management has contributed to the creation of moral hazard, without preventing the crises from spreading (Bordo and James, 2000).

${ }^{11}$ Eichengreen's analysis, in this case, is focused on the Asian experience. Given the recent developments of the European crisis, it becomes questionable to what extent countries do abstain from criticizing their
} 
The needs for cooperation, in addition to incentives in the opposite direction, are hindered by the asymmetry in the process of global governance in finance, as in other areas, reflecting the underlying reality and directly affecting its results. Besides the "classic" asymmetry of the international system between developed and developing countries, observed by Strange in the small group of States enjoying a disproportional share of influence (Cohen, 2000), one could wonder about the existence of crossed asymmetries, that apply not only to state actors, but also to non-state ones, inside and among groups. In this sense, Strange affirms, in Casino Capitalism, that the financial system affects all, but some more than others; those that elaborate the rules usually win or, at least, lose less than others. Furthermore, in the international system, since a basic structure is established, authority begins to be socially built, being more than sheer and plain power (Cohen, 2000).

The level of deregulation of the financial system and the persistence of imbalances that led to the most recent economic crisis are evidence that the most powerful actors, States or not, are capable of molding the international financial system envisaging their private benefits, with no further considerations regarding the common good. The stability produced up to that point, thus, is minimalist, a false stability in reality. Actually, an illusion of stability and prosperity was created producing new distorted incentives to actors in the system, culminating in the crisis these same actors were trying to avoid at the beginning of the process. By producing the achievable stability as a public good, paradoxically, its second dimension, as economic security, ends consolidated. The idea of systemic stability is spread, but the actions of States and private actors are aimed at exclusive gains. Private actors, furthermore, are not as concerned with systemic security, as they are with restrictions to their activities. Having assurances provided by national governments or international institutions, as the IMF, which are justified by the systemic importance of these actors, banks and other international financial institutions get involved in high-risk actions in search of bigger returns. Since the risks are socially shared and the gains are exclusive, a vicious circle is created by moral hazard and incentives towards destabilizing practices by private agents. The international financial system, from the 1990s, has become a casino that, according to Strange, "has gone mad [...] wildly foolish to let the financial markets run so far ahead, so far beyond the control of state and international authorities" (Strange, 1998, apud Verdun). Taylor (2002) completes arguing that the liberalization of capital markets and exchange speculation have expanded the reach of the casino to comprise the whole world.

It is clear, thus, that the governance of international finance depends on actions involving state and non-state actors. One of the greatest problems, in this sense, is the excessive focus of projects and analysis on States. This methodological approach, though, reveals a specific perception of the international fi-

neighbors. Reinforcing Eichengreen's argument, it is possible to understand the contemporary European context as far past crises' prevention. Actually, the European Union, the European System of Central Banks or the Stability and Growth Pact were not able to alter the damaging behaviors that several countries had been adopting since the introduction of the Euro. 
nancial system, in which non-state agents are perceived as instability elements that must be controlled. The responsibilities of States are not disregarded, either, although the coordination of economic policies is considered more difficult due to the restrictions on States' sovereignty that such measures would entail. Partially diverging from the idea that States are part of the solution, Eichengreen (2009a) lists a series of ways to avoid a crisis as the recent one through the strengthening of the IMF and the use of more currencies as reserves, potentially the Euro and the Yuan, even though this one would be a long-term solution, in addition to regulatory reforms that aim at containing private actors. Investing on strengthening the Fund, nevertheless, seems to go against global trends in governance in the direction of democratization of the international relations and of the decision-making processes. For Eichengreen, though, it would be precisely the opposite, because it would imply further insulating the institution in relation to national governments represented in it. One notices here the conception that a supranational organ must control States, just like private agents must be controlled by States or internationally.

Convinced by the "benevolent" role of the State, the efforts currently seem to advance toward the democratization of the governance of the financial system, in a process understood from a State perspective. This process, if we take the arguments presented by Ocampo, can facilitate cooperation and the attainment of a wide stability as a public good inasmuch as the participation and the feeling of belonging would lead to more commitment. The democratization referred here can be verified, for instance, in the substitution of the G8 for the G20 as the main global economic forum and in the reforms in the shares of the IMF and of the World Bank. The FSF has been widened, as well, with the creation of the Financial Stability Board, in the beginning of 2009. Even if we take the perspective of Ocampo and join Strange, dismissing, thus, the argument of Eichengreen, based on the inseparability of economy and politics, the democratization process is not immune to criticism, though.

Firstly, it is a democratization limited in the number of States comprised. Although the G20 encompasses $90 \%$ of the world GDP, more than $35 \%$ of the world population is not represented in that forum. Decisions taken there, however, undoubtedly affect the lives of everyone. For Dailami and Masson, just as it occurred with the G7, the G20 lacks legitimacy (Dailami and Masson, 2009, apud Lins and Silva, 2011). Secondly, democratization is limited because it does not include systemically important private actors. In the decision-making fora, differently from other areas as environment or human rights, no opening for non-state actors can be noticed. It is questionable, though, how worthy is the participation of these actors when their main concern is not in the systemic security, but in diminishing the restrictions over their activities. Their participation, actually, could contribute to empower these institutions vis-à-vis the States and the system as a whole, aggravating the instability the fora try to control.

Still regarding the actors comprised by the democratization, it would be interesting to ask whether the participation of civil society, understood as the polis, is 
possible or positive. Given that civil society does not participate in the formation of financial policies even domestically, it is hard to imagine the feasibility of a demand for it to participate internationally. Considering that economic decisions are technical, best taken given the insulation of its decision-makers, it does not seem simple a justification for the inclusion of civil society in the decision-making process either. Recurring to Strange once more, we have that if insulation protects the formulators of public policies from popular pressures, it is not capable of armoring them completely against more powerful interest groups in the national and international societies. That assumption also lies on the belief that the bureaucrat is neutral, that is, he will look after the interests of society as whole, and not after his own interests, an expectation that does not find confirmation in reality (Krueger, 1990). ${ }^{12}$ If economy and politics cannot be dissociated, arguments for more openings become more attractive over those for insulation. A mid-ground must be found, though, between the control over government by elite groups and the use of public policies with populist purposes.

The presence and influence of non-state actors, although recognized, does not entail an adequate approach. The currently chosen way to include them in the governance of the financial system, as stated, has been granting States more control over financial institutions acting in their territories. It is not the lack of regulation per se the biggest problem regarding private agents, however, but the lack of enforcement mechanisms. The problem is not exclusively national, either. As a transnational challenge, the absence of international regulation and implementation institutions is a serious obstacle to guaranteeing international financial stability. Not even regionally there are authorities with regulation and verification capacity, as would be expected in the European case. Nowadays, the existing control is decentralized and potentially problematic if rules are not adopted universally: actors can simply transfer their headquarters or regulated operations to more lenient jurisdictions.

Ultimately, what is observed today is more a concentration of power in State actors than a democratization and, among these, power is concentrating in those that already have a bigger sway over the international system. These States are those in which systemically important private actors are located and those are the governments capable of rescuing them in case of insolvency. If on one hand government control over these institutions is fragile and contingent, on the other hand to increase this control favors the politicization of private actors and the use of these actors by States as tools for foreign policy, reinforcing the asymmetric structure of the financial system, in particular, and that of the international system as a whole.

\footnotetext{
${ }^{12}$ Krueger's argument is not, initially, in favor of more participation of politics in the economy, but this is a natural inference from her work. If government is not neutral and if it is not possible to trust government agents, in order for the State to provide those public goods for which it is responsible (which are a limited group for Krueger), the only solution is to improve control over the bureaucracy. In this sense, more democracy and transparency would be better than insulation.
} 


\section{CONCLUSION}

The contemporary international system presents growing challenges to governance building, in addition to the classic opposition between markets and States that predominate in economics. The search for economic stability, understood not only as the absence of crises, but also as the inexistence of meaningful and recurrent imbalances, is hindered considerably by the emergence of new actors, state and non-state ones, and by the modification of the context in the financial system since Bretton Woods. The abandonment of exchange controls, the development of a private international capital market and the dissemination of offshore operations have diminished the importance of the IMF as the backbone of the international financial system, as well as its capacity to exert control over States economies. States were also affected, including through liberalization policies they implemented, causing their own economies to escape their control.

In the governance of the financial system, besides the role of States, it is indispensable to consider the part of private actors, perhaps even more than in other regimes because of the disproportional role these actors have in the economy as a whole. Differently from other areas, though, the financial system, with its main function of redistributing resources, has solid justifications to remain independent from the government. As the 2007 crisis revealed, though, it is not possible that these actors continue to act completely unimpeded around the globe, getting involved in high-risk operations with socially shared costs. Dealing with the State/ private sector interface, thus, building governance in international finance must look after conciliation between credibility and independence of private actors and government regulation.

It is not evident, either, the institutional structure capable of assuring stability from a State perspective. The criteria used for sharing responsibilities are eminently political, not economic. If we consider the base of Susan Strange arguments, though, that economy and politics cannot be dissociated, would it not be better that the selection of the main actors is openly political than hidden under a veil of technicality? It is equally questionable whether sheer economic sway is the best criterion to be part of a high-level cooperation forum. Maybe other elements, as regional leadership or the ability to coordinate with other actors are more valid than the GDP. The subprime crisis has revealed that the biggest economies in the world are not invulnerable to economic disturbances, which they are not capable of controlling and may be even fomenting.

The complexity of the theme of governance in the international financial system is, for sure, inherent to economics and tends to be aggravated as it follows the development and ripening of the capitalist economy. Between low and high politics, between power and cooperation, between public and private, the economy and the financial sector, specifically, cannot be easily framed by "off the shelf" analytical models. With a strong historical component, economic phenomena cannot be understood from a purely normative perspective, either; one must consider the context 
in which power disputes occur, the underlying structure to incentive systems and the actors involved, with their distinct capacities and interests.

\section{REFERENCES}

BORDO, Michael D. and JAMES, Harold (2000). The International Monetary Fund: Its Present Role in Historical Perspective. NBER Working Paper 7724. 57 pages.

COHEN, Benjamin J. (2000). Money and Power in World Politics. In: LAWTON, Thomas et al. (eds.). Strange Power: Shaping the Parameters of International Relations and International Political Economy. Aldershot: Ashgate. pp. 91-113.

DENT, Christopher M. (2007). Economic Security. In: COLLINS, Alan (ed.). Contemporary Security Studies. Oxford: Oxford University Press. pp. 204-221.

EICHENGREEN, Barry (2009a). The Financial Crisis and Global Policy Reform. Prepared for the Federal Reserve Bank of San Francisco's conference on Asia and the Financial Crisis, Santa Barbara, California, 19-21 October. 49 pages. Available at:

$<$ http://emlab.berkeley.edu/ eichengr/finan_crisis_glob_pol_10-09.pdf>.

EICHENGREEN, Barry (2009b). Financial Re-regulation, yes. But Europe's Cacophony of Ideas Is Counter-Productive. Europe's World. pp.102-107. Available at:

$<$ http://emlab.berkeley.edu/ eichengr/financial_re-reg.pdf >.

KAUL, Inge et al. "Defining Global Public Goods", In: KAUL, Inge et al. (eds.) Global Public Goods: International Cooperation in the $21^{\text {st }}$ Century. Oxford: Oxford University Press, 1999. pp. 2-19.

KRUEGER, Anne O. (1990). Government Failures in Development. Journal of Economic Perspectives, Vol. 4, No. 3, pp. 9-23.

LINS, Maria Antonieta D.T. and SILVA, Leandro P. (2011). Brazil and the G20: Recent Development Strategy and Strength among "New" Emerging Economies. In: HOFMEISTER, Wilhelm (ed.). G20: Perceptions and Perspectives for Global Governance. Konrad-Adenauer-Stiftung, Singapore. pp. 21-30.

OCAMPO, José Antonio (2002). Reforming the International Financial Architecture: Consensus and Divergence. In: NAYAR, Deepak (ed.) Governing Globalization: Issues and Institutions. New York: Oxford University Press. pp.287-307.

STRANGE, Susan (1996). The Retreat of the State: the Diffusion of Power in the World Economy. Cambridge Studies in International Relations, 49. Cambridge University Press. 218 pages.

TAYLOR, Lance (2002). Global Macroeconomic Management. In: NAYAR, Deepak (ed.) Governing Globalization: Issues and Institutions. New York: Oxford University Press. pp. 51-77.

UNDERHILL, Geoffrey R.D. (2000). Global Money and the Decline of State Power. In: LAWTON, Thomas et al. (eds.). Strange Power: Shaping the Parameters of International Relations and International Political Economy. Aldershot: Ashgate. pp. 115-135.

VERDUN, Amy C. (2000). Money Power: Shaping the Global Financial System. In: LAWTON, Thomas et al. (eds.). Strange Power: Shaping the Parameters of International Relations and International Political Economy. Aldershot: Ashgate. pp. 77-90. 